\title{
The effect of leadership style, organizational culture and motivation on employee performance
}

\author{
Nuning Nurna Dewi ${ }^{{ }^{*}}$ and Rudi Wibowo ${ }^{a}$
}

${ }^{a}$ Economic's Lecture of Universitas Maarif Hasyim Latif, Indonesia

\begin{tabular}{l}
\hline C H R O N I C L E \\
\hline Article history: \\
Received: October 16, 2019 \\
Received in revised format: \\
January 302020 \\
Accepted: February 10, 2020 \\
Available online: \\
February 10, 2020 \\
\hline Keywords: \\
Leadership Style \\
Organizational Culture \\
Motivation \\
Performance
\end{tabular}

A B S T R A C T

This study aims to determine the effect of leadership style, organizational culture and motivation partially on the performance of permanent lecturers at Universitas Maarif Hasyim Sidoarjo. The object of this research is associated with the development of the world of education, while the scope of research concentrates on the area of Ngelom, Megare Sepajang Taman, Indonesia. The type of research is descriptive with explanatory research. Sampling is conducted by proportional stratified random sampling method. The population of this study includes all lecturers at Maarif Hasyim Latif University. Data analysis uses multiple linear regression analysis. The results show that Leadership Style, Organizational Culture, and Motivation simultaneously influence on the Performance of Permanent Lecturers.

(C) 2020 by the authors; licensee Growing Science, Canada

\section{Introduction}

Human resource management is one of the controlling elements and the most important factor in all forms of organizations. The effectiveness of the organization in realizing the organization's vision, mission and goals cannot be separated from the figure of a leader. Leadership is the backbone of the organization's operation since without proper and good leadership it will be difficult to realize the goals of the organization, even to adjust to the changes that develop within and outside the organization. The condition of Indonesia's national economic competition is increasingly competitive and requires companies and organizations to be motivated to further improvement on the performance of human resources in achieving productivity. Thus, competition is getting tougher among universities compared with other state and private universities in Indonesia. Motivation at work is one of the factors that can affect employee performance, where motivation at work must be considered by the company or institution in order to learn from the expected motivation of employees to have a work spirit in achieving company goals. According to Zamanan et al. (2020) there are two methods to increase employee motivation, namely direct motivation by meeting material and non-material needs of employees as well as indirect motivation by providing all facilities to support work. Leadership style and organizational culture can influence the behavior of employees in a company or institution. Performance is a very important concept for employees, because the effectiveness of an organization is very dependent on the people who manage the organization as expected for the improvement of employee performance in both public and private organizations. This performance is a desire to achieve organizational goals. Performance can be interpreted as a person's success in carrying out a task and work. In addition to leadership style, the organization or company can succeed in achieving its goals which can be influenced by organizational culture. Organizational culture namely a pattern, beliefs, norms and values that run within a company affect the behavior or human resources' behavior or employees in the organization and it affects the employee performance. Soleman et al. (2020) argue that organizational culture is a basic pattern of thinking and act correctly. Employees who have understood the values in an organization will make these values as an organizational personality. These values and beliefs will be realized into their daily behavior at work. Universitas Ma'arif Hasyim Latief Sidoarjo

* Corresponding author.

E-mail address: nuning@dosen.umaha.ac.id (N. Nurna Dewi)

(C) 2020 by the authors; licensee Growing Science, Canada doi: $10.5267 /$ j.msl.2020.2.008 
is a private university which is a large family institution from Yayasan Pendidikan dan Sosial Ma'arif(YPM) which is located on J1. Ngelom Megare, Taman-Sidoarjo. At the beginning of its establishment, this campus was a specialized college that underwent a transformation process into a university in 2014 ago. Through this process of transformation is expected to encourage and motivate all elements of the organization to move towards a new spirit that is more dynamic.

This study aims to determine the positive influence of leadership style, organizational culture and motivation on the performance of permanent lecturers at universitas maarif hasyim latief sidoarjo. The study also finds out the effect of leadership style, organizational culture and motivation simultaneously on the performance of permanent lecturers at universitas maarif hasyim latief sidoarjo.

\section{Literature review}

\subsection{Definition of human resource management}

The increasing of a management role in an organization or company can result in increased attention to the importance of the human resource management function in the company. Attention that was initially focused on a single point of concentration of capital and mechanics of the company. Now, companies are paying greater attention to issues related to human resource factors. Human resource is one of the factors of production in a company, but plays a very large role for the progress of the company. Human resources are needed by all companies both small and large companies. Human resource management has the function of managing the human element properly to obtain an appropriate workforce and be satisfied with the implementation of their work. Thus, it will affect the performance of employees so that facilitate the realization of the objectives of a company.

\subsection{The function of Human Resource Management}

According to Obeidat, B. Y. (2012), the functions of human resource management are as follows,

1. Managerial Function
a.) Planning
b.) Organizing
c.) Directing
d.) Controlling

2. Operational Functions
a.) Procurement
b.) Development
c.) Compensation
d.) Integration
e.) Maintenance
f.) Discipline
g.) Termination or Termination of Employment (separation)

\subsection{Leadership Style}

\subsubsection{Definition of Leadership Style}

The role of leadership is very important in organizational management. Leadership is defined into individual characteristics, ways of influencing others, habits, interactions, positions in the organization and perceptions about the legitimate influence. According to Woods (2004), leadership is the process of influencing or giving an example to his/her followers through a communication process in an effort to realize the organizational goals. Leadership is the process of guiding, directing and influencing the thoughts, feelings, behavior and actions of others to be moved towards certain goals. Leadership plays a very important role and it can even be said to be very decisive in the achievement of predetermined goals. Leadership style represents the philosophy, skills and attitude of leaders. According to Bono and Judge (2004) leadership style is a way used by leaders in interacting with followers or subordinates. Another opinion states that the leadership style is a pattern of behavior (words and actions) of a leader that is felt by others (Erben \& Güneşer, 2008). Seeing the leadership style definitions from these experts, it can be concluded that leadership style is a way taken by someone in order to practice his/her leadership. The leadership style can be categorized as Authoritarian leadership style, Democratic leadership style and Free leadership style.

\subsection{Organizational Culture}

\subsubsection{Definition of Organizational Culture}

Organizational culture is the norms, values, philosophy, assumptions, beliefs, organizational habits, etc. (contents of organizational culture) that are developed over a long time by the founders, leaders and members of the organization that are socialized and taught to new members and applied in organizational activities so that it can affect the mindset, attitudes, and behavior of organizational members in producing products, serving consumers, and achieving organizational goals (Schrodt, 2002). Based on the understanding/definition of organizational culture according to some experts it can be seen that what is meant by organizational culture is the organizational value system carried out by members of the organization, which then influences the way of organizations and behave from members of the organization. According to Ravasi and Schultz (2006), the function of culture in an organization, namely: 
a. Culture has a role of setting boundaries.

b. Culture can give identity to members of the organization.

c. Culture facilitates the emergence of broader commitments and on individual interests.

d. Culture increases the stability of the social system.

e. Culture as a mechanism for creating meaning and control that guides and shapes employee attitudes and behavior.

\subsubsection{The Elements of Organizational Culture}

Organizational culture is a pattern of beliefs and values outlined in the form of norms or guidelines for members of the organization in behavior and solving organizational problems. Schrodt (2002) suggests the elements contained in organizational culture, namely as follows:
a. Basic Assumptions
c. Leader
b. Confidence
d. Problem solving guidelines
e. Sharing value
f. Inheritance (learning process)
g. Adjustment (adaptation)

\subsection{Work Motivation}

\subsubsection{Definition of Work Motivation}

Motivation is defined as an impulse or mobilizer in human beings that can bring up, direct, and organize behavior (Inceoglu et al., 2012). Motivation is the process by which a person's efforts are energized, directed and sustained towards the realization of a goal. Whereas Ambrose and Kulik (1999) defines motivation as giving the power of movement that gives rise to the excitement of one's work so that they want to work together, work effectively and be integrated with all their efforts to achieve satisfaction. Motivation is a psychological factor that shows an individual's interest in work, satisfied feeling and take responsibility for the activity or work performed. Thus, from the opinions of some experts we can conclude that motivation is an encouragement that can result in someone doing an effort or behavior in a certain way as an expression of his/her needs. Based on some of the above understanding, then it can be concluded that motivation is an impulse that arises in a person to carry out a job with high enthusiasm towards achieving a goal in the organization.

\subsection{Motivation Theory}

Early theories about motivation consists of,

1. Maslow's needs hierarchy theory,

2. $\mathrm{X}$ and $\mathrm{Y}$ McGregor Theory,

3. The two-factors theory from Frederick Herzberg,

4. Theory of Three Needs from McClelland.

\subsection{Employee Performance}

\subsubsection{Definition of Employee Performance}

Basically, performance includes something that is individual, because each employee has a different level of ability to carry out his/her duties. The following are the views of performance according to some experts:

a. Robbins and DeNisi (1994) state employee performance (work performance) as the result of a work in quantity and quality achieved by an employee in carrying out their duties in accordance with the responsibilities given to him.

b. According to Brayfield and Crockett (1955) performance is the result of work achieved by a person in carrying out the tasks imposed on him based on skill, experience, sincerity and time.

c. According to Elnaga and Imran (2013) performance namely is to carry out an activity that carries out in accordance with responsibilities with the desired results.

Based on the definitions given on employee performance we can conclude that employee performance is the achievement by employees in carrying out a job in an organization, so that the desired goals can be carried out in accordance with the targets set.

\subsubsection{Factors influencing performance}

Every employee, whether a company employee, social employee or government employee is established with the intention of achieving predetermined goals and objectives to improve the employee's performance. 


\section{Conceptual Framework}

To examine the leadership style and organizational culture on the permanent lecturer performance, the framework of the proposed study is as follows.

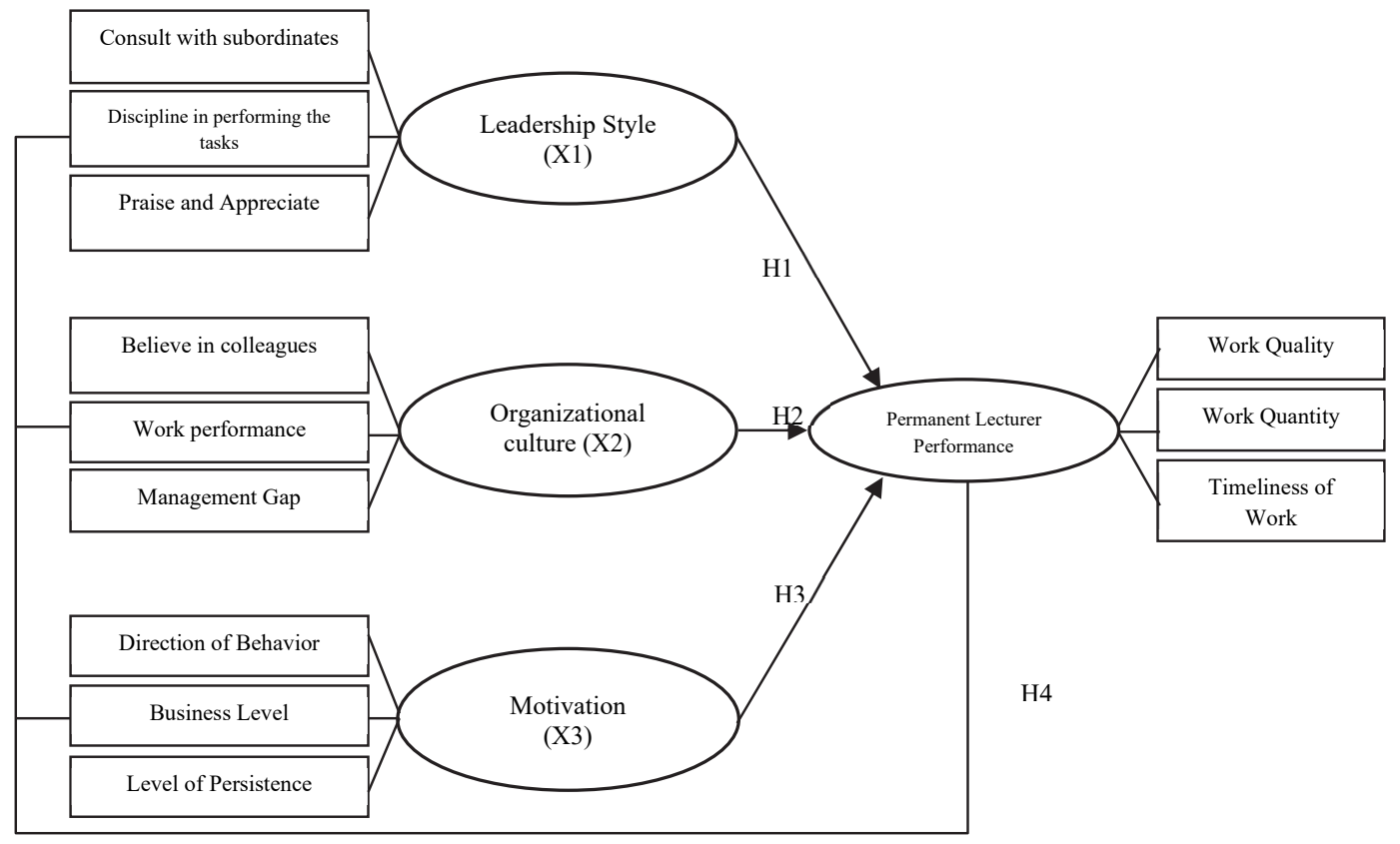

\subsection{Hypothesis}

Fig. 1. The proposed study

Based on the background and problem formulation that has been outlined, the research hypothesis proposed is as follows: $\mathrm{H}_{1}$ : Leadership style has a positive influence on the performance of permanent lecturers at Universitas Maarif Hasyim Latief. $\mathrm{H}_{2}$ : Organizational Culture has a positive influence on the performance of permanent lecturers at Universitas Maarif Hasyim Latief.

$\mathrm{H}_{3}$ : Motivation has a positive effect on the performance of permanent lecturers at Maarif Hasyim Latief University.

$\mathrm{H}_{4}$ : Leadership Style, Organizational Culture and Motivation have positive effects on the performance of permanent lecturers at Maarif Hasyim Latief University.

\subsection{Research method}

The objective of this research is the development of the world of education, while the scope of research namely in Sidoarjo more precisely in the Ngelom area, Megare Sepajang Taman. This study uses the type of research that uses the Hypothesis, because with this hypothesis the writer will have a temporary answer to the existing problem, where this research is descriptive which explains the composition and characteristics of the relevant unit groups. The data has been collected by conducting a survey through the distribution of questionnaires that addressed to lecturers of universitas maarif hasyim latief. Sampling will be conducted by proportional stratified random sampling. Sampling is strived in such a way, which is expected to obtain a representative sample. In this study, the authors use a Likert scale, which asks respondents to indicate the degree of agreement or disagreement. Population is a generalization area that consists of objects or subjects that have certain quantities and characteristics determined by researchers to be analyzed and then conclusions are determined. So that the population is not only people, but also objects and other natural objects. The target population in this study is a permanent lecturer at Maarif Hasyim Latif University. The sample is part of a number of characteristics possessed by the population. If the population is large, researchers impossible to learn all that contained in the population, for example due to limited funds, manpower, and time, then researchers can utilize samples taken from that population. What is obtained from the sample, the conclusion can be applied to the population as well. Therefore, the sample taken from the population must be truly representative. To facilitate the determination of the number of samples taken is determined by the following,

where :

$$
\mathrm{n}=\frac{\mathrm{N}}{1+\mathrm{N}(\mathrm{e})^{2}}
$$

\footnotetext{
$\mathrm{n}=$ Sample size

$\mathrm{N}=$ Population

$\mathrm{e}=$ Percentage of looseness due to desirable sampling errors
} 
The population of respondents from the University of Maarif Hasyim Latief Sidoarjo was 70, so the sample that we took as research if using the Slovin formula with a confidence level of $95 \%$ and an error rate of 5\% was equal to 59.6 using the formula and the study sample for a population of 70 and a $50 \%$ confidence level is 60 people. This research is used to determine the influence of leadership style, organizational culture and motivation on the performance of permanent lecturers. This study uses Multiple Regression analysis with data management using SPSS Statistics version 23. In addition, to be able to obtain data from respondents properly, the questionnaire as a research data collection instrument must meet two requirements, namely validity and reliability. Therefore, the questionnaire must be tested first for the level of validity and reliability (Mas'ud, 2004).

1. Validity test aims to measure the validity of a questionnaire. A questionnaire is said to be valid if the question (indicator) contained in the questionnaire is able to reveal something that will be measured by the questionnaire (Ghozali, 2006). Validity test is done by comparing the value of $r$ calculate with $r$ table namely looking for $(\mathrm{df})=\mathrm{N}-\mathrm{k}$, what is meant by $\mathrm{N}$ is the number of samples, and $\mathrm{k}$ is the number of independent variables of the study. If $\mathrm{r}$ calculate $>\mathrm{r}$ table, and has a positive value, then the question is said to be valid (Ghozali, 2006).

2. The reliability test aims to measure the permanence or reliability or consistency of a questionnaire. A questionnaire is said to be reliable or consistent if the respondent's answers to the question points in the questionnaire remain consistent or stable from time to time (Ghozali, 2006). Measurement of reliability in this study by means of one shot, namely running measurements only once then the results are compared with other questions, or measuring the correlation between answers of questions in the questionnaire. Therefore, researchers used the SPSS program for windows SPSS to measure reliability with the Cronbach Alpha $(\alpha)$ statistical test. A variable is declared reliable if it gives a value of $\alpha>$ 0,60 (Nunnally quoted by Ghozali, 2006).

\subsection{Classical Assumption Test}

\subsubsection{Multicollinearity test}

This test is conducted to determine whether there is a correlation between independent variables in the regression model. A good regression should not occur correlation between independent variables. To detect the presence of multicollinearity in the regression model, by looking at the value of tolerance, and the opposite namely the variance inflation factor (VIF). Low tolerance value $=$ high VIF value (because VIF $=1$ / Tolerance). The cut-off value used in showing the presence of multicollinearity is a tolerance value $<0,10$, or the same as a VIF value $>10$ (Ghozali, 2006).

\subsubsection{Normality Test}

This test is conducted to determine whether in the regression model, confounding or residual variables have a normal distribution. A good regression model namely has normal or nearly normal distribution. The normal distribution namely forming a diagonal straight line, and the diagonal line will be compared with residual data plotting. If the residual data distribution is normal, the line that represents the actual data will follow the diagonal line (Ghozali, 2006).

\subsection{Multiple Linear Regression Analysis}

Multiple regression analysis is an analysis conducted to determine the effect of the relationship between two variables namely the $\mathrm{X}$ variable (independent) and Y variable (dependent). Multiple linear regression analysis is an analysis that has the aim to determine whether there is a dependency relationship, and the direction of the relationship between two or more independent variables $(\mathrm{X})$ with the dependent variable $(\mathrm{Y})$ whether positive or negative (Priyatno, 2008). The equation of multiple linear regression is as $\mathrm{Y}=\mathrm{a}+\mathrm{b}_{1} \mathrm{X}_{1}+\mathrm{b}_{2} \mathrm{X}_{2}+\mathrm{b}_{3} \mathrm{X}_{3}+\mathrm{e}$ where:

$$
\begin{aligned}
& \mathrm{Y}=\text { Employee performance variable } \\
& \mathrm{X} 1=\text { Leadership style variable } \\
& \mathrm{X} 2=\text { Organizational culture variable } \\
& \mathrm{X} 3=\text { Motivational variable }
\end{aligned}
$$

\author{
$\mathrm{a}=$ Constants \\ $\mathrm{b}_{1} \mathrm{~b}_{2}=$ Regression coefficient \\ $\mathrm{e}=$ Other variables not included in the study
}

\subsection{Hypotheses testing}

The $\mathrm{R}^{2}$ test is intended to measure the percentage of variation of the independent variable in the multiple linear regression models in explaining the variation of the dependent variable. The determination coefficient value is between 0 (zero) and 1 (one). A small $\mathrm{R}^{2}$ value (zero) means that the ability of the independent variables to explain the variation of the dependent variable is very limited. Vice versa, the $\left(\mathrm{R}^{2}\right)$ value approaching 1 (one) means that the independent variables provide almost all the information needed to predict the variation of the dependent variable (Ghozali, 2006). T-test aims to test the significant relationship between variables $\mathrm{X}$ and $\mathrm{Y}$, whether the variables of $\mathrm{X} 1, \mathrm{X} 2$, and $\mathrm{X} 3$ really affect the $\mathrm{Y}$ variable individually or partially (Ghozali, 2006). The hypothesis used in this study is: 
Ho: Partially there is no significant effect between the independent variables on the dependent variable.

The F test basically aims to show whether all independent variables, namely leadership style $\left(\mathrm{X}_{1}\right)$, organizational culture $\left(\mathrm{X}_{2}\right)$, and motivation $\left(\mathrm{X}_{3}\right)$ included in the model have any influences on the dependent variable, namely permanent lecturer performance (Y). The criteria used are:

a. Ho : $\beta \mathrm{i}=0$, means that simultaneously there is no significant influence of the independent variables, leadership style (X1), organizational culture (X2), and motivation (X3), on the dependent variable, namely the performance of permanent lecturers (Y)

b. Ha : $\beta 1>0$ means that simultaneously there is a significant positive effect of the independent variables, leadership style (X1), organizational culture (X2), and motivation (X3), on the dependent variable, namely the performance of permanent lecturers (Y).

Fig. 2 shows personal characteristics of the participants who participated in this survey.

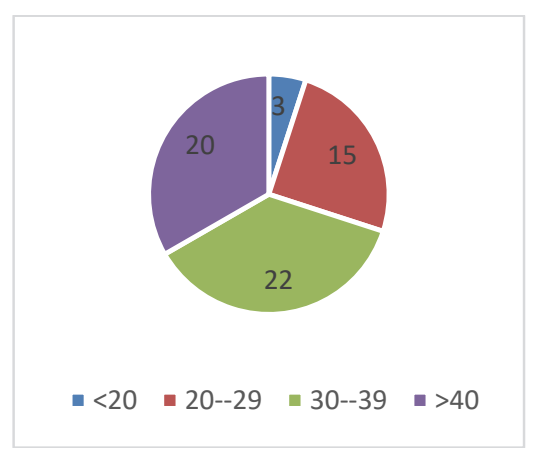

Age

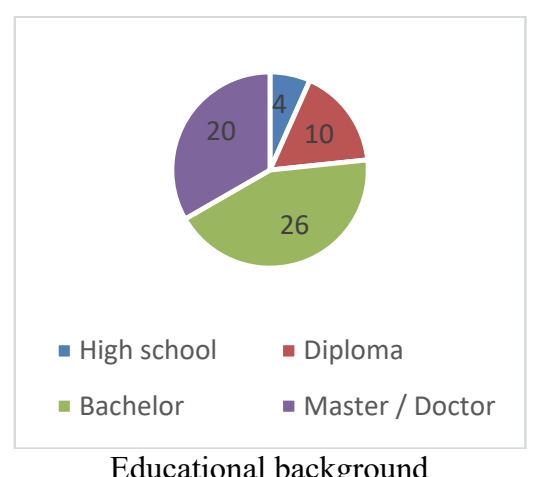

Educational background

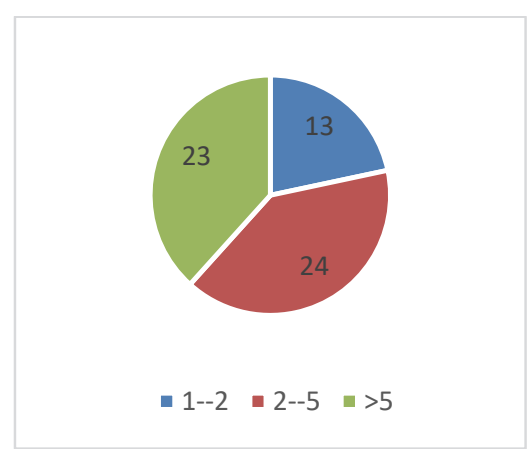

Income $\times 10^{6} \mathrm{Rp}$.

Fig. 2. Personal characteristics of the participants

In our survey, $45 \%$ of the participants were male and the remining 55\% were female. Moreover, as we can observe from Fig. 2, most participants had, at least, bachelor degree of science and were less than 40 years old. Finally, the average income of the participants in terms of Indonesian currency are shown in the figure. The results of the validity test can be seen in Table 1 as follows,

Table 1

The summary of Pearson correlation test

\begin{tabular}{|c|c|c|c|c|}
\hline Variable & Statement & r calculate & $\mathrm{r}$ table & Conclusion \\
\hline \multirow{3}{*}{$\begin{array}{l}\text { Leadership Style } \\
\left(\mathrm{X}_{1}\right)\end{array}$} & $\mathrm{X}_{1.1}$ & 0,898 & 0.2542 & Valid \\
\hline & $\mathrm{X}_{1.2}$ & 0,862 & 0.2542 & Valid \\
\hline & $\mathrm{X}_{1.3}$ & 0,812 & 0.2542 & Valid \\
\hline \multirow{3}{*}{$\begin{array}{l}\text { Organizational Culture } \\
\left(\mathrm{X}_{2}\right)\end{array}$} & $\mathrm{X}_{2.1}$ & 0,822 & 0.2542 & Valid \\
\hline & $\mathrm{X}_{2.2}$ & 0,862 & 0.2542 & Valid \\
\hline & $\mathrm{X}_{2.3}$ & 0,778 & 0.2542 & Valid \\
\hline \multirow{3}{*}{ Motivation $\left(\mathrm{X}_{3}\right)$} & $\mathrm{X}_{3.1}$ & 0,897 & 0.2542 & Valid \\
\hline & $\mathrm{X}_{3.2}$ & 0,897 & 0.2542 & Valid \\
\hline & $\mathrm{X}_{3.3}$ & 0,784 & 0.2542 & Valid \\
\hline \multirow{3}{*}{$\begin{array}{l}\text { Permanent Lecturer Performance } \\
\text { (Y) }\end{array}$} & $\mathrm{Y}_{.1}$ & 0,860 & 0.2542 & Valid \\
\hline & $\mathrm{Y}_{.2}$ & 0,915 & 0.2542 & Valid \\
\hline & $\mathrm{Y}_{.3}$ & 0,831 & 0.2542 & Valid \\
\hline
\end{tabular}

Based on the results of Table 1, it is known that the indicators of the independent variables consisting of Leadership Style $\left(\mathrm{X}_{1}\right)$, Organizational Culture $\left(\mathrm{X}_{2}\right)$, and Motivation $\left(\mathrm{X}_{3}\right)$ as well as the dependent variable namely Permanent Lecturer Performance (Y) show valid results. Reliability test is used to determine the reliability of the instrument from the questionnaire used with the provisions that if the value of Cronbach alpha (a) is greater than 0,6 then a variable is said to be reliable (Ghozali, 2006). The reliability test results can be seen in Table 2 as follows,

Table 2

The summary of the Cronbach alpha

\begin{tabular}{lll}
\hline Variable & Alpha & Conclusion \\
\hline Leadership Style $\left(\mathrm{X}_{1}\right)$ & 0,819 & Reliable \\
Organizational Culture $\left(\mathrm{X}_{2}\right)$ & 0,754 & Reliable \\
Motivation $\left(\mathrm{X}_{3}\right)$ & 0,821 & Reliable \\
Permanent Lecturer Performance $(\mathrm{Y})$ & 0,937 & Reliable \\
\hline
\end{tabular}


Based on Table 2, it can be seen that the variables used in this study are reliable. The variance inflation factor (VIF) test aims to examine whether the regression model in this study shows a correlation among the independent variables. Table 3 presents the results of this factor.

Table 3

Multicollinearity with VIF

\begin{tabular}{llll}
\hline Variable & Tolerance & VIF & Conclusion \\
\hline Leadership Style $\left(\mathrm{X}_{1}\right)$ & 0,195 & 5,124 & Multicollinearity free \\
Organizational Culture $\left(\mathrm{X}_{2}\right)$ & 0,325 & 3,079 & Multicollinearity free \\
Motivation $\left(\mathrm{X}_{3}\right)$ & 0,273 & 3,661 & Multicollinearity free \\
\hline
\end{tabular}

The results of the VIF indicate that all variables are free from multicollinearity since all VIF values are smaller than 10 and tolerance values greater than 0.1 . Normality test aims to test whether the dependent variable and independent variables regression model both have normal distributions or not. Based on the results of the Kolmogorov Smirnov test on the residual regression using the SPSS program we have obtained the result as $Z=0.933$ with Asymp Sig. $=0.349$, which means that all variables are normally distributed. Finally, Table 4 shows the results of regression analysis.

Table 4

The summary of the results of regression analysis

\begin{tabular}{lll}
\hline \multirow{2}{*}{ Model } & \multicolumn{2}{l}{ Unstandardized Coefficients } \\
& B & Std. Error \\
\hline Constant & -0.200 & 0.334 \\
Leadership Style $\left(X_{1}\right)$ & 0.416 & 0.194 \\
Organizational Culture $\left(X_{2}\right)$ & 0.378 & 0.173 \\
Motivation $\left(X_{3}\right)$ & 0.374 & 0.173 \\
\hline
\end{tabular}

$Y=-0.200+0.416 X_{1}+0.378 X_{2}+0.374 X_{3}+e_{i}$

From this result can be interpreted:

1. The constant value is -0.200 which states that without the influence of the independent variables of Leadership Style $\left(\mathrm{X}_{1}\right)$, Organizational Culture $\left(\mathrm{X}_{2}\right)$, and Motivation $\left(\mathrm{X}_{3}\right)$, the value of the dependent variable namely the Performance of Permanent Lecturer $(\mathrm{Y})$ is -0.200 .

2. The value of the regression coefficient of the independent variable of Leadership Style $\left(\mathrm{X}_{1}\right)$ is 0.416 , and the coefficient value implies that when the value of the independent variable $X_{1}$ is increased by one percent it will cause an increase in the value of the dependent variable namely the Performance of Permanent Lecturer (Y) by 0.416 percent assuming that the other variables have no changes.

3. The value of the regression coefficient of the independent variable of Organizational Culture $\left(\mathrm{X}_{2}\right)$ is 0.378 , the value of the coefficient means that when the value of the independent variable $\mathrm{X}_{2}$ is increased by one unit it will cause an increase in the value of the dependent variable namely the Performance of Permanent Lecturer (Y) by 0.378 units assuming that the other variables have no changes.

4. The value of the regression coefficient of the independent variable of Motivation $\left(\mathrm{X}_{3}\right)$ is 0.374 which means that if the value of the independent variable $\mathrm{X}_{3}$ is increased by one unit it will cause an increase in the value of the dependent variable namely the Performance of the Permanent Lecturer (Y) amounted by 0.374 units assuming that the other variables have remained unchanged.

5. $\mathrm{e}_{\mathrm{i}}$ shows the confounding factors outside the model studied.

The correlation coefficient aims to measure the level of closeness of the relationship between the independent variable and the dependent variable. The results of SPSS calculations regarding the correlation coefficient and determination shown by the table below. In our survey, Adjusted R-Square is equal to 0.704 which means that the independent variables can approximately describe $70 \%$ of the changes in dependent variable. To test the hypothesis, we have used the $t$ test to show the partial effect of each independent variable on the dependent variable and the results are summarized in Table 5 as follows,

\section{Table 5}

Calculation Results of the $t$ test

\begin{tabular}{llll}
\hline Variable & $t_{S i g}$ & Result & Information \\
\hline Leadership Style $\left(\mathrm{X}_{1}\right)$ & 0.036 & Significant & $0.036<0.05$ \\
Organizational Culture $\left(\mathrm{X}_{2}\right)$ & 0.033 & Significant & $0.033<0.05$ \\
Motivation $\left(\mathrm{X}_{3}\right)$ & 0.034 & Significant & $0.034<0.05$ \\
\hline
\end{tabular}


As we can observe from the results of Table 5, all t-values are meaningful when the level of significance is five percent. Next, we present the results of ANOVA test in Table 6 as follows,

Table 6

The summary of the results of Analysis of Variance (ANOVA test)

\begin{tabular}{llllll}
\hline Model & Sum of Squares & df & Mean Square & F & Sig. \\
\hline Regression & 24.974 & 3 & 8.325 & & \multirow{2}{*}{0.000} \\
Residual & 9.749 & 56 & 0.174 & & \\
\hline Total & 34.723 & 59 & & & \\
\hline
\end{tabular}

\section{Conclusion}

Based on the results of the research, several conclusions can be drawn as follows:

1. Leadership Style has a partial significant effect on the Performance of Permanent Lecturers at the University of Maarif Hasyim Sidoarjo.

2. Organizational Culture has a partial significant effect on the Performance of Permanent Lecturers at the University of Maarif Hasyim Sidoarjo.

3. Motivation has a partial significant effect on the Performance of Permanent Lecturers at the University of Maarif Hasyim Sidoarjo.

4. Leadership Style, Organizational Culture, and Motivation have simultaneously significant effects on the Performance of Permanent Lecturers at Universitas Maarif Hasyim Sidoarjo.

Based on the results of this study, it is expected that Universitas Maarif Hasyim Sidoarjo can improve organizational culture by always giving awards for lecturers' work performance. As a future research, the effects of the other factors could be considered on the dependent variable and we leave it as a future research for interested researchers.

\section{References}

Ambrose, M. L., \& Kulik, C. T. (1999). Old friends, new faces: Motivation research in the 1990s. Journal of Management, 25(3), 231-292.

Bono, J. E., \& Judge, T. A. (2004). Personality and transformational and transactional leadership: a meta-analysis. Journal of Applied Psychology, 89(5), 901.

Brayfield, A. H., \& Crockett, W. H. (1955). Employee attitudes and employee performance. Psychological Bulletin, 52(5), 396.

Elnaga, A., \& Imran, A. (2013). The effect of training on employee performance. European journal of Business and Management, 5(4), 137-147.

Erben, G. S., \& Güneşer, A. B. (2008). The relationship between paternalistic leadership and organizational commitment: Investigating the role of climate regarding ethics. Journal of Business Ethics, 82(4), 955-968.

Ghozali, I. (2006). Aplikasi analisis multivariate dengan program SPSS.

Inceoglu, I., Segers, J., \& Bartram, D. (2012). Age-related differences in work motivation. Journal of Occupational and Organizational Psychology, 85(2), 300-329.

Obeidat, B. Y. (2012). The relationship between human resource information system (HRIS) functions and human resource management (HRM) functionalities. Journal of Management Research, 4(4), 192-211.

Ravasi, D., \& Schultz, M. (2006). Responding to organizational identity threats: Exploring the role of organizational culture. Academy of Management Journal, 49(3), 433-458.

Robbins, T. L., \& DeNisi, A. S. (1994). A closer look at interpersonal affect as a distinct influence on cognitive processing in performance evaluations. Journal of Applied Psychology, 79(3), 341.

Schrodt, P. (2002). The relationship between organizational identification and organizational culture: Employee perceptions of culture and identification in a retail sales organization. Communication Studies, 53(2), 189-202.

Soleman, M., Armanu, A., Aisjah, S., \& Sudjatno, S. (2020). Islamic job satisfaction, organizational commitment, and intention to leave: Moderating role of Islamic work ethics. Management Science Letters, 10(6), 1359-1368.

Woods, P. A. (2004). Democratic leadership: drawing distinctions with distributed leadership. International Journal of Leadership in Education, 7(1), 3-26.

Zamanan, M., Alkhaldi, M., Almajroub, A., Alajmi, A., Alshammari, J., \& Aburumman, O. (2020). The influence of HRM practices and employees' satisfaction on intention to leave. Management Science Letters, 10(8), 1887-1894.

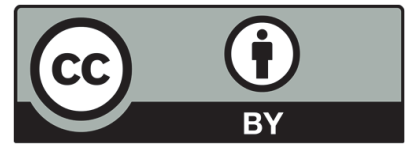

(C) 2020 by the authors; licensee Growing Science, Canada. This is an open access article distributed under the terms and conditions of the Creative Commons Attribution (CC-BY) license (http://creativecommons.org/licenses/by/4.0/). 